\title{
Microencapsulation Technology to Enhance the Viability of Probiotic Bacteria in Fermented Foods: An Overview
}

\author{
Himani J. Chaudhary and Ami R Patel* \\ Division of Dairy Microbiology, Mansinhbhai Institute of Dairy and Food Technology-MIDFT, Mehsana-384002, Gujarat \\ State, India
}

*Corresponding author: ami@midft.com

Received: 06-07-2019

Revised: $17-10-2019$

Accepted: 25-11-2019

\begin{abstract}
Microencapsulation is one of the promising technologies to enhance the viability of probiotics microorganisms in functional foods. It also helps to extend the shelf life of many fermented food products. Lactic acid bacteria were microencapsulated within the concept of the immobilized cell technology (ICT) from many years for continuous fermentation processes and improved biomass production. But, these microcapsules are artificially created to support the growth of the probiotics and provide protection from harsh external environments. For microencapsulation of bifidobacteria and lactobacilli, polysaccharides like alginate, gelan, carrageenan, chitosan and starch are the most commonly used materials. Emulsion, extrusion, spray drying, and adhesion to starch are some of the commonly applied methods for microencapsulation. However, there are still significant hurdles with respect to currently available methods for probiotic cell microencapsulation. This is mainly due to the fact that important characteristics of microcapsules based on ICT appear to be in conflict with the requirements arising from an application of probiotic microcapsules in food products, with particle size and inappropriate matrix characteristics being the most prominent ones. The aim of this review is to give a critical overview of the current approaches regarding the microencapsulation of probiotic microorganisms for food applications, especially in fermented milk products and to report on emerging developments.
\end{abstract}

Keywords: Microcapsules, coating material, viability, alginate, extrusion, spray drying

Probiotics were defined as "live microbial feed supplements that have beneficial effects to the host by improving the microbial balance of their intestines" (FAO, 2002). The term probiotic contains a broad range of microorganism, especially lactic acid bacteria (lactobacilli and lactococci), some other food grade bacteria (bifidobacteria, propionibacteria, etc.) and yeasts since they can be alive till the intestine and given rise positive health effects to the host upon ingestion (Burgain et al. 2011). Probiotics can compete with pathogens and hence prevent them from adhering to the intestine (Tuomola et al. 1999). Probiotic intake also improves intestinal health by regulating or controlling native microflora; stimulates and develops the immune system; synthesizes and enhances nutrient bioavailability; lower the symptoms of lactose intolerance; and decrease the risk of some other diseases (Heidebach et al. 2012).

The main problem with the handling of probiotic organisms is their stability during processing of foods and sustaining viability during storage even at refrigeration temperature. A number of technologies have been develop to enhance or improve the viability of probiotics in different food matrixes; among that encapsulation technique have been found to be most promising. Microencapsulation is described 
as a technology for enveloping small solid particles, liquid droplets or gasses in a coating, which forms microcapsules of about 1 to $1000 \mu \mathrm{m}$ in size (Nazzaro et al. 2012). Microencapsulation is a process whereby single liquid or solid (core) droplet or molecules are filled, covered or coated with such a continuous polymeric (shell) surface to create capsules in the micron to microcapsule ranges (Kavitake et al. 2018; Vidhyalakshmi et al. 2009).

Incorporation of microencapsulated probiotic microorganisms to food products is relatively a new functional food concept. Microencapsulation can be used to maintain the viability of probiotic bacteria during processing and storage of dairy or food product. Microencapsulation have been employed successfully on some dairy products such as yoghurt (Brinques and Ayub, 2011; Krasaekoopt et al. 2003), cheeses (Abd-Elhamid et al. 2012; Amines et al. 2014), and ice cream (Karthikeyan et al. 2014), fruit juices (Phoem et al. 2015), fermented vegetables (Song et al. 2018), bakery products and ready to eat cereals (Vitaglione et al. 2015), etc. The method of encapsulation involves the insertion of the active substance into another substance wall material which creates particles of different scales (Kavitake et al. 2018). In current paper, we have critically reviewed the significance of different microencapsulation methods used to enhance the viability of for lactic acid bacteria including probiotics in fermented and non fermented foods.

\section{Purpose of Microencapsulation Technology}

There are several purposes for utilizing microencapsulation technology to diverse food types or pharmaceutical preparations such as: (i) control release of the active components for delayed (timed) or long acting (sustained) release, (ii) it can stabilize drug which are susceptible to humidity, light or oxygen, (iii) it may avoid incompatibility between drug, (iv) it prevents evaporation of core material which is volatile in nature, (v) it helps to minimize toxicity or risk and gastrointestinal discomfort and, (vi) it may also results in modification in the other components that they encounter during GI transit for microencapsulation (Bansode et al. 2010; Keshari et al. 2016).

\section{Components of Microencapsulation Technology}

The main components of microencapsulation techniques are core material and coating materials. The core material consists of a certain substance covered by solid or liquid material, which may differ in its composition, which may discharge or dissolve the liquid component. Active components, diluents and accelerators are part of the solid core (Chávarri et al. 2012).

The coating substance is able to establish a film along with the core material: being nonreactive to the core material and chemically compatible; as well as provide the required characteristics for coating like optical properties, stability, impermeability strength and flexibility (Chávarri et al. 2012; Keshari et al. 2016). There some properties of coating material like in certain circumstances controlled release, inert to active substances, core material stabilization, economical, no high viscosity, non- hygroscopic, tasteless, film-forming, stable, soluble in an aqueous media or solvent or melting. Example of coating material such as water soluble resins, water insoluble resins (gum arabic, starch, gelatin), enteric resins(cellulose acetate phthalate) and waxes and lipids.

\section{Coating Materials for Probiotic Encapsulation}

Various polymers like starch, alginate, gellan gum, xanthan gum, chitosan, gelatin and $\kappa$ carrageenan found there use as coating material in microencapsulation. Further, as mentioned by Patel and Prajapati (2013) microbial exopolysaccharides (EPS) protect microbial cells in their natural environment against severe conditions like osmotic stress, desiccation, antibiotics or other toxic compounds, in context to this beta-glucans have been reported to protect probiotic microbial cells in stimulated GI conditions (Shah et al. 2016). Several studies on encapsulation of LAB such as Lc. lactis and L. paracasei (Léonard et al. 2015), L. acidophilus and Bif. lactis (Darukaradhya et al. 2013), L. plantarum 
(Corbo et al. 2016) and L. curvatus MBSa2 (Barbosa, et al. 2015) were reported by means of different coating materials with respect to their viability, functionality, and application.

(i) Alginate: When the $\mathrm{Ca}^{2+}$ gelling ions disperse into the alginate system because of its interesting properties like non toxic, easily forming gel matrices around bacterial cells, mild condition of processing required for their efficiency, proper resolve the gut and releases the entrapped cells into the intestine, biocompatible and low cost (Chávarri et al. 2012). The alginate bead gelation occurs by cross- linkage.

(ii) Gellan Gum and Xanthan Gum: Gellan gum consists of a repeating unit of four monomers such as glucose, glucuronic acid, glucose and rhamnose. Gellan gum is microbial polysaccharide which derived from Pseudomonas elodea. In the case of encapsulate of probiotic cells a xanthan-gellan gum mixture has been used and, in comparison to alginate, the mixture has a high acid tolerance (Sun and Griffiths, 2000).

(iii) K-Carrageenan:Carrageenan is alinear polymer consisting D-galactose units alternatively linked by $\alpha-(1-3)$ and $\beta(1-4)$ bonds; kappa ( $\kappa)$, iota $(\tau)$, and lambda $(\lambda)$ are the types of carrageenan (Solanki et al. 2013). $\kappa$-Carrageenan is a natural polymer with sulphated polysaccharides. It is commonly used in the form of gelling agent, texture improver, thickening agent or food stabilizer. Probiotic cells are encapsulated with k-carrageenan beads which maintain the bacteria in viable state, but the formed gels are damaged or brittle and cannot withstand stress (Chen and Chen, 2007).

(iv) Chitosan: Chitosan has excellent film- forming skills. Chitosan is more used as an external shell of capsules made of anionic polymer than probiotic bacteria with alginate are covered by alginate encapsulation because the chitosan coating provides a good way of delivering viable bacterial cells to the colony under stimulated GI conditions (Krasaekoopt et al. 2004; Lee et al. 2004; Solanki et al. 2013).

(v) Gelatin: In pure form, the polymer is translucent, brittle, colorless or slightly yellow, tasteless and odorless. This thermo reversible gel can be used as alone or in cooperation with gellan gum like polysaccharides due to amphoteric nature (Krasaekoopt et al. 2004). Earlier, the survival of encapsulated Bifidobacterium adolescentis $15703 \mathrm{~T}$ by alginate coated gelatin microspheres was improved in gastro-intestinal tract (Annan et al. 2008). On the other hand, to protect the encapsulated LAB under simulated GI conditions Nawong et al. (2016) developed novel food-grade gelatinmaltodextrin microspheres cross-linked with transglutaminase (TGase).

(vi) Starch: Resistant starch is the starch which is not digested by pancreatic enzymes (amylases) in the small intestine. Resistant starch can reach the colon where it will be fermented (Haralampu, 2000). The incorporation of HiMaize starch alone (Iyer and Kailaspathy, 2005) or in combination with chitosan (deAraujo et al. 2016) improved the encapsulation of viable bacteria compared with the bacteria encapsulated without starch.

(vii) Milk proteins: The proteins possess excellent gelling properties and hence can be used to encapsulate bioactive components (Livney, 2010). It has been used in the encapsulation of probiotic cells by Heidebach et al. (2009). While Ying et al. (2013) revealed that compared to resistant starch, whey proteins provided better protection for L. rhamnosus GG in apple juice alone during $4{ }^{\circ} \mathrm{C}$ storage.

(viii) Cellulose Acetate Phthalate (CAP): CAP is utilized for encapsulation of probiotic bacteria due to its good protection, safety nature and being physically inert characteristics under simulated GI conditions. This polymer is insoluble at acidic $\mathrm{pH}(<5)$ but soluble at 
$\mathrm{pH}>6$ because of its ionizable phthalate groups (Mortazavian et al. 2007).

\section{Morphology of Microcapsules}

Microcapsule morphology depends on core material and coating material (shell) deposition. Three basic types of morphology are used for making microcapsules as shown in Fig. 1: (1) Mononuclear type- In this microcapsules contain shell around core, (2) Polynuclear or matrix type- In this microcapsule have core enclosed within the shell, and (3) Coated matrix type encapsulation-core material is distributed homogenously into shell material.

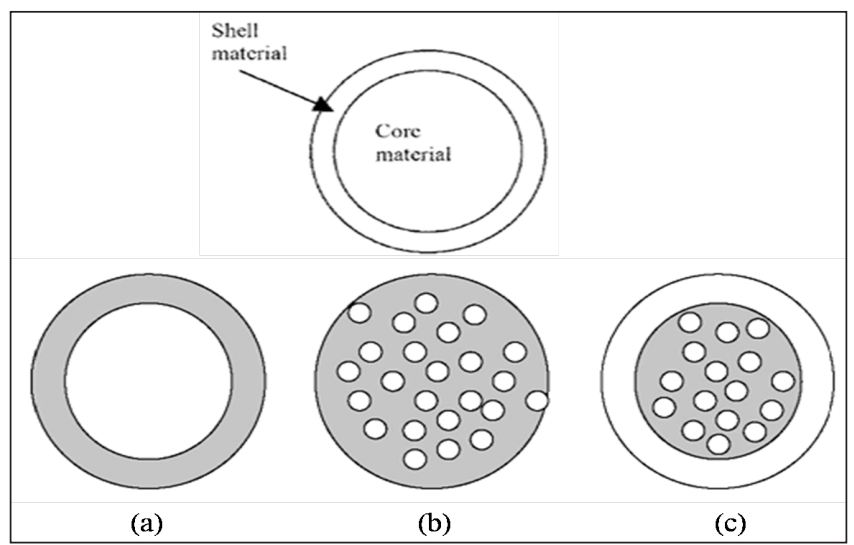

Fig. 1: Morphology of microcapsules: (a) Reservoir or Mono-core type, (b) Matrix or Poly-core type (c) Coated Matrix type

\section{Techniques for Microencapsulation of Probiotics}

Spray drying, emulsion, extrusion, thermal gelation, supercritical fluid, fluidized bed, droplet freezing, coacervation, solvent evaporaion, polymerization, interfacial polymerization, and droplet gelation are the key microencapsulation methods to encapsulate bioactive substances into carrier materials. A number of factors like physical and chemical characteristics of core material, carrier/coating materials and their proposed appliance in food matrix influence the choice of suitable encapsulation process. Among these, spray drying, emulsion, and extrusion have been proven to be most effective for probiotic microorganisms and hence, further discussed in the text below.
1. Spray drying: In food industries spray drying is standard method for turning or convert liquid into dry powder. In recent year spray drying has been used to encapsulate probiotic cells, not only for drying purpose but also for the encapsulation (Fig. 2a). In this case, spray dried mixtures of probiotic cell concentrates with aqueous solution of specific polymers, such as starch (O'Riordan et al. 2001), gum arabic (Desmond et al. 2002), gelatin (Lian et al. 2003), whey protein isolate (Picot and Lacroix, 2004), maltodextrin mixed with gum arabic (Su et al. 2007) and ß-cyclodextrin mixed with gum arabic (Zhao et al. 2008) and their ability to protect the probiotic cells against adverse condition was investigated. The spray drying process is controlled by air flow, feed and material temperature. The benefits of spray drying are the speed and the relatively low cost. It is a highly reproducible method and the most significant is that it is ideal for industrial applications. One downside of spray drying is the use of high temperature that is incompatible with bacteria's survival.

2. Emulsification: Emulsification is a chemical technique for encapsulating probiotic living cells and using hydrocolloids as materials that encapsulate them (Fig. 2b). The theory of this technique is based on the continuous and discontinuous phases. This method is easy to scale up and gives the bacteria a high survival rate (Chen and Chen, 2007). The emulsion technique allows the creation of the desired size of the microcapsules by varying agitation rate and water/oil ratio (Kailasapathy, 2009). The beads of gel can be injected into a second polymer solution to build a layer of coating that provides additional cell security or many offer improved organoleptic properties.

3. Extrusion method: Extrusion is a physical procedure which encapsulates probiotic cells and uses hydrocolloids as encapsulating substance. In this method involves the injection of the solution containing the cells at the higher 

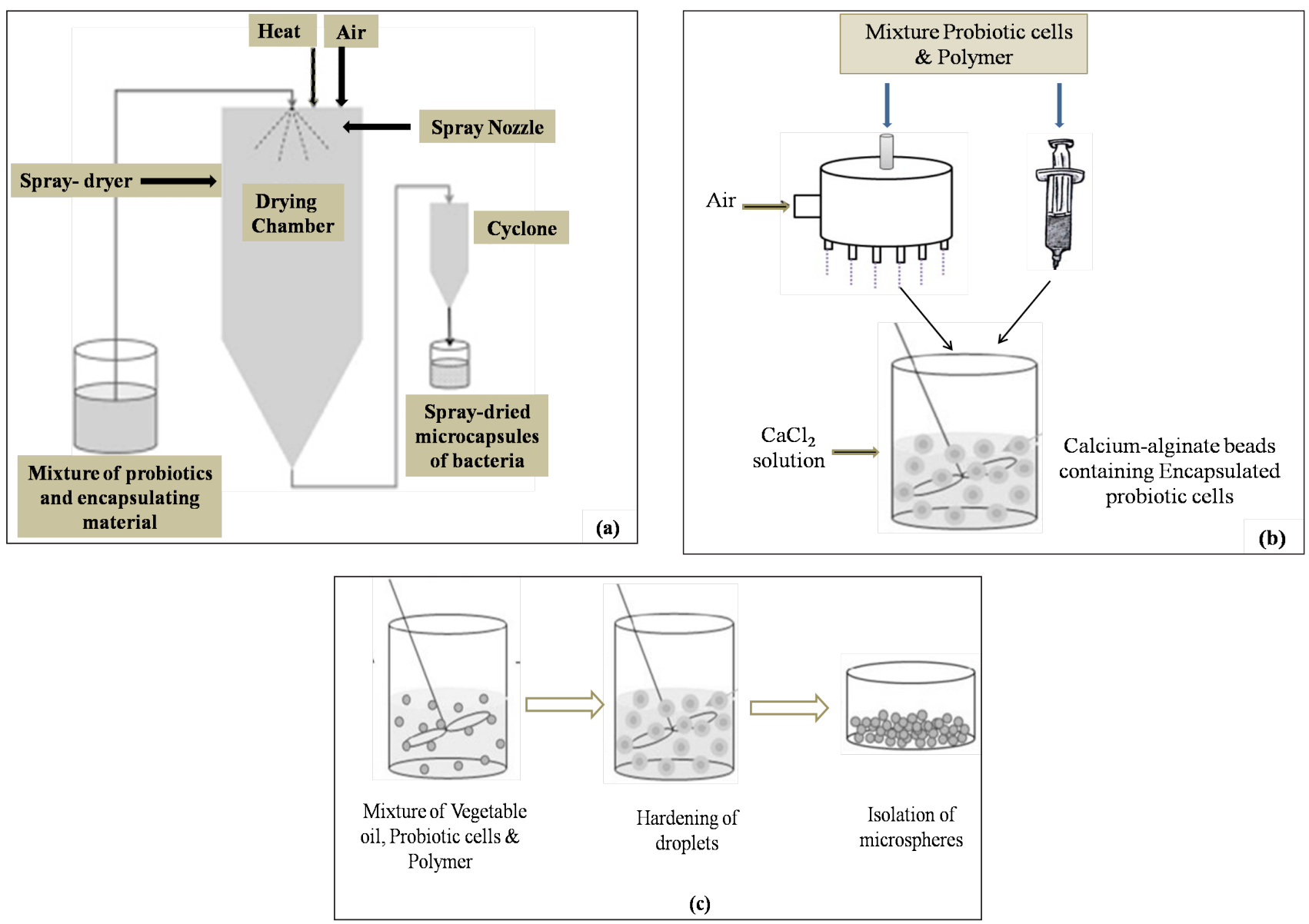

Fig. 2: Schematic representation of (a) Spray drying, (b) Extrusion method, and (c) Emulsification method for microencapsulation of probiotics

pressure through nozzle as depicted in Figure$2 \mathrm{~b}$ (Burgain et al. 2011). Extrusion is one of the ancient and popular methods of producing hydrocolloid capsule using a simple and low cost procedure that minimizes injury to probiotic cells while maintaining a relatively higher viability (Mortazavian et al. 2007). Beads size diameter, mostly depends on the range between syringe and hardening solution, form of polymer, viscosity, concentration and mainly extruder orifice diameter. It is a simple and low cost process, which uses a gentle procedure that does not damage viable probiotic cells. The major disadvantage of this method is due to slow formation of micro beads, it is difficult to use in large-scale production.
The major outcomes of several studies dealing with microencapsulation of probiotics by employing any of the above discussed techniques in dairy and food products are compiled in Table 1. In a recent investigation, $L$. acidophilus was microencapsulated by external gelation in alginate-gelatin (AG) and alginate-gelatin-fructooligosaccharides (AGF) microbeads in context to increase the viability of probiotic culture (Silva et al. 2018). When exposed to simulated GIT, microencapsulation provided better protection to the probiotic cells especially to those who were encapsulated with FOS since promoted the formation of a more interconnected network, which contributed to better protection of cells and controlled delivery. 
Table 1: Major outcomes of some studies dealing with microencapsulation in dairy and food products

\begin{tabular}{|c|c|c|c|c|}
\hline Material & Bacterial strain & Product & Major Outcome & Reference \\
\hline Sodium alginate & $\begin{array}{l}\text { Bifidobacterium } \\
\text { longum } 15708\end{array}$ & Cheddar cheese & $\begin{array}{l}\text { Cheddar cheese containing } \\
\text { encapsulated B. longum produced with } \\
\text { emulsion process showed a good survival } \\
\text { with } 2 \text { log CFU/mL reduction after } 21 \\
\text { days, as compared to droplet extrusion- } \\
\text { encapsulated B. longum and free cells with } 3 \\
\text { and } 4 \log \text { CFU/mL reductions, respectively }\end{array}$ & $\begin{array}{l}\text { Amine et al. } \\
2014\end{array}$ \\
\hline $\begin{array}{l}\text { Calcium } \\
\text { alginate and } \\
\text { whey protein } \\
\text { concentrate } \\
\text { beads }\end{array}$ & $\begin{array}{l}\text { Lb. acidophilus } \\
(L A-5) \text { and } L b . \text { casei } \\
(N C D C-298)\end{array}$ & Ice cream & $\begin{array}{l}\text { The viable cell count of } L b \text {. acidophilus (LA- } \\
5 \text { ) and } L b \text {. casei (NCDC-298) in the free state } \\
\text { in prepared ice cream mixture was } 5.1 \pm 0.2 \\
\times 10^{9} \mathrm{cfu} / \mathrm{ml} \text { and } 4.3 \pm 0.2 \times 10^{9} \mathrm{cfu} / \mathrm{ml} \text { at day } \\
\text { one and the numbers were decreased to } \\
4.1 \pm 0.3 \times 10^{6} \text { and } 1.9 \pm 0.2 \times 10^{7} \mathrm{cfu} / \mathrm{ml} \text { after } 180 \\
\text { days of storage at }-23^{\circ} \mathrm{C} \text { respectively. After, } \\
\text { the probiotic survival rate raised at of } 30 \text { per } \\
\text { cent during the same period of storage. }\end{array}$ & $\begin{array}{l}\text { Karthikeyan } \\
\text { et al. } 2014\end{array}$ \\
\hline Milk proteins & $\begin{array}{l}\text { Bifi. adolescentis } \\
\text { ATCC } 15704\end{array}$ & Kariesh cheese & $\begin{array}{l}\text { Survival of encapsulated Bif. adolescentis in bile } \\
\text { solution was significantly enhanced }(\mathrm{p}<0.05) \\
\text { compared to the free cells; encapsulation } \\
\text { protected cells in Kariesh cheese during cold } \\
\text { storage as compared to free cells }\end{array}$ & $\begin{array}{l}\text { Abd- } \\
\text { Elhamid, } \\
2012\end{array}$ \\
\hline Sodium alginate & $\begin{array}{l}\text { Lb. paracasei ssp. } \\
\text { paracasei LBC-1 } \\
(\mathrm{LBC}-1 \mathrm{e})\end{array}$ & $\begin{array}{l}\text { Mozzarella } \\
\text { cheese }\end{array}$ & $\begin{array}{l}\text { Some reductions were observed in both free } \\
\text { and encapsulated LBC-1e during heating } \\
\text { and stretching, with encapsulated LBC-1e } \\
\text { surviving slightly better. During storage, a } \\
\text { decrease was observed in total LAB, but no } \\
\text { statistically significant decrease was observed } \\
\text { in LBC-1e }\end{array}$ & $\begin{array}{l}\text { Ortakci et al. } \\
2012\end{array}$ \\
\hline $\begin{array}{l}\text { Sodium alginate } \\
\text { or pectin }\end{array}$ & $\begin{array}{l}\text { Lb. } \\
\text { plantarum BL011 }\end{array}$ & Yoghurt & $\begin{array}{l}\text { Under refrigerated storage viability of } \\
\text { immobilized cells were greatly enhanced } \\
\text { compared to the free microorganisms, and the } \\
\text { treatments showing the lowest loss of viability } \\
\text { were those of } 4 \%(\mathrm{w} / \mathrm{v}) \text { pectin, } 3 \%(\mathrm{w} / \mathrm{v}) \\
\text { sodium alginate coated with chitosan and a } \\
\text { mixture of } 2 \%(\mathrm{w} / \mathrm{v}) \text { sodium alginate and } 2 \% \\
(\mathrm{w} / \mathrm{v}) \text { pectin, respectively. Loss of viability } \\
\text { of immobilized L. plantarum in } 3 \% \text { alginate } \\
\text { coated with chitosan in yogurt was of } 0.55 \mathrm{log} \\
\text { cycles during } 38 \text { days of storage }\end{array}$ & $\begin{array}{l}\text { Brusch- } \\
\text { Brinques } \\
\text { and Ayub, } \\
2011\end{array}$ \\
\hline $\begin{array}{l}\text { NA-alginate } \\
\text { [extrusion] or } \\
\text { k-carragenan } \\
\text { [emulsion tech.] }\end{array}$ & $\begin{array}{l}\text { Bif. bifidum BB- } \\
12 \text { and } L b . \\
\text { acidophilus LA-5 }\end{array}$ & $\begin{array}{l}\text { White-brined } \\
\text { cheese }\end{array}$ & $\begin{array}{l}\text { Both techniques were effective in keeping } \\
\text { the numbers of probiotic bacteria higher } \\
\text { than the level of the therapeutic minimum } \\
\left(>10^{7} \mathrm{cfu} \mathrm{g}^{-1}\right) \text { : While the counts of probiotic } \\
\text { bacteria decreased appro. } 3 \text { log in control } \\
\text { cheese in which probiotics were used as free } \\
\text { cells, the decrease was more limited in the } \\
\text { cheeses containing microencapsulated cells } \\
\text { (appro. } 1 \text { log) }\end{array}$ & $\begin{array}{l}\text { Ozer et al. } \\
2009\end{array}$ \\
\hline
\end{tabular}




\begin{tabular}{|l|l|l|l|l|}
\hline $\begin{array}{l}\text { Milk Proteins } \\
\text { (goats' milk) }\end{array}$ & $\begin{array}{l}\text { L. acidophilus LA5, } \\
\text { Bifidobacterium } \\
\text { animalis sub sp. } \\
\text { lactis BB12, and } \\
\text { Propionibacterium } \\
\text { jensenii 702 }\end{array}$ & Milk powder & $\begin{array}{l}\text { All three probiotics were able to maintain } \\
\text { satisfactory viability levels }\left(10^{6}-10^{8} \mathrm{cfu} / \mathrm{g}\right) \\
\text { after spray drying. While during storage } \\
\text { encapsulation of mixed cultures did not affect } \\
\text { the viability during storage at } 4{ }^{\circ} \mathrm{C}, \text { while a } \\
\text { significantly reduction occurred at } 30^{\circ} \mathrm{C} .\end{array}$ & $\begin{array}{l}\text { Ranadheera } \\
\text { et al. } 2015\end{array}$ \\
\hline Sodium alginate & LAB KCC-42 & $\begin{array}{l}\text { Radish Kimchi } \\
\text { and Simulated } \\
\text { Gastrointestinal } \\
\text { Juices }\end{array}$ & $\begin{array}{l}\text { Survival rate of free and encapsulated LAB } \\
\text { KCC-42 was } 6.85 \times 10^{5} \text { and } 7.48 \times 10^{5} \mathrm{CFU} / \\
\text { ml, respectively; The viability count was } \\
\text { significantly higher than nonencapsulated } \\
\text { LAB in simulated gastrointestinal juices (acid, } \\
\text { bile, and pancreatin) and under radish kimchi } \\
\text { fermentation environment; The production of } \\
\text { metabolites bacterial population was high in } \\
\text { encapsulated LAB samples }\end{array}$ \\
\hline
\end{tabular}

Microencapsulation of probiotic strain Bifidobacterium lactis was done in jussara (Euterpe edulis M.) juice by Paim et al. (2016) through spray drying method. There was $1 \log$ cycle reduction in the viable count of probiotic cells during the process. Another study states that among alginate, chitosan and hydroxypropyl methylcellulose (HPMC), no single matrix fibre could improve the viability of L. acidophilus NCIMB 701748 from production through storage and digestion (Yonekura et al. 2014). Compared to control, HPMC and sodium alginate, chitosan improved survival rates in simulated GI conditions, but it caused large losses of cell viability during spray-drying.

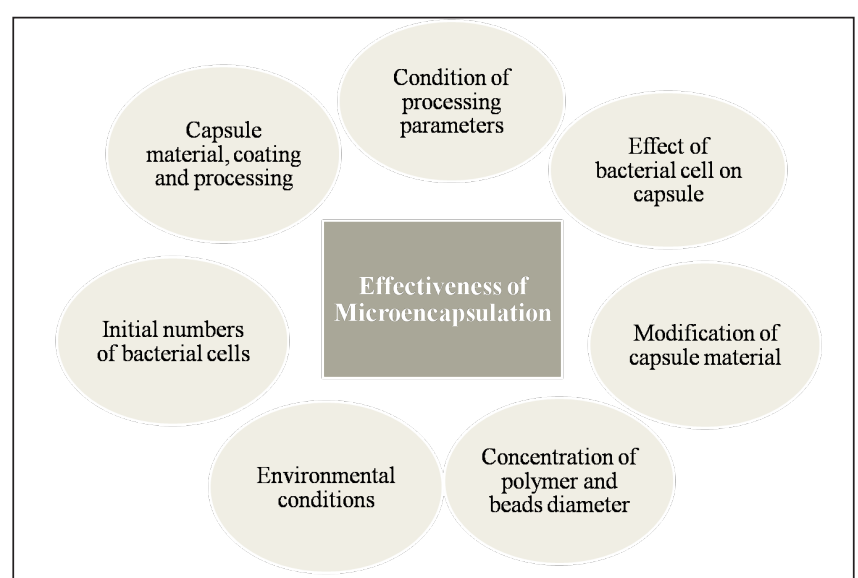

Fig. 3: Factors affecting effectiveness of microencapsulation process for probiotic microorganisms

As depicted in Fig. 3, some factors such as environmental condition, effect of bacterial cell on capsule, modification of capsule material, condition of processing factors, initial concentration of microbial cells, capsule material, coating and processes, characteristics of capsule with respect to environment and concentration of polymer and bead diameter affects the effectiveness of microencapsulation (Kavitake et al. 2018; Solanki et al. 2013). These problems can be further overcome by selecting appropriate encapsulation method, core material, coating material and other processing conditions.

\section{Pros and Cons of Microencapsulation Technology}

Some benefits of microencapsulation technology includes: (i) it is possible to use enzymes in microencapsulated form in food products to accelerate ripening and flavor development, (ii) it has improved viability and stability of starter culture, (iii) they helps in protect the compounds against UV radiation, heat, and/or oxidation, (iv) shelf-life of bioactive components/drugs is improved by preventing degradative reaction, and (v) handling of liquid as solids is possible (Heidebach et al. 2012; Jyothi et al. 2012).

Several disadvantages of microencapsulation are (i) it is costly approach, (ii) this causes reduction in shelf life of hygroscopic drugs, (iii) different dosage forms like tablet, capsules, and lozenges cannot be encapsulated by single microencapsulation process, 
and (iv) certain times coating may not be uniform this can effect release pattern of drug in the body (Heidebach et al. 2012; Kavitake et al. 2018).

\section{CONCLUSION}

The sustainability viability of starter cultures including probiotic microorganisms in the fermented foods and gastrointestinal environment are major challenges at industrial scale. Microencapsulation is one of the promising technology emerged in recent years which has potential to improve the viability of probiotic microorganism as well as other bioactive components in different applications. In context to probiotics, at commercial level, spray drying is more advantageous microencapsulation technique among all other methods employed for the probiotics while, at small scale or laboratory level emulsion or extrusion method is more beneficial. In the encapsulated form, the probiotics are protected from bacteriophage and harsh environments, such as freezing and gastric solutions. In dairy products, specifically in case of yoghurt, ice-cream and cheese during storage (shelflife) on an average 1-2 log cycle reduction have been observed which is significantly very low as compared to free cells (3-4 log cycle reduction). The survival rate of probiotic bacteria with prebiotic is higher than microencapsulated probiotic without prebiotic. Microencapsulation enhances the viability of bacteria without any alteration in the sensory properties of dairy products.

\section{REFERENCES}

Abd-Elhamid, A.M. 2012. Production of functional kariesh cheese by microencapsulation of Bifidobacterium adolescentis ATCC 15704. Advance Journal of Food Science and Technology, 4(2): 112-117.

Amine, K.M., Champagne, C.P., Raymond, Y., St-Gelais, D., Britten, M., Fustier, P. and Lacroix, M. 2014. Survival of microencapsulated Bifidobacterium longum in Cheddar cheese during production and storage. Food Control, 37: 193-199.

Annan, N.T., Borza, A.D. and Hansen, L.T. 2008. Encapsulation in alginate-coated gelatin microspheres improves survival of the probiotic 15703T during exposure to simulated gastro-intestinal conditions. Food Research International, 41: 184-193.
Bansode, S.S., Banarjee, S.K., Gaikwad, D.D., Jadhav, S.L. and Thorat, R.M. 2010. Microencapsulation: a review. International Journal of Pharmaceutical Sciences Review and Research, 1(2): 38-43.

Brusch-Brinques, G. and Ayub, M.A.Z. 2011. Effect of microencapsulation on survival of Lactobacillus plantarum in simulated gastrointestinal conditions, refrigeration and yogurt. Journal of Food Engineering, 103: 123-128.

Burgain, J., Gaiani, C., Linder, M. and Scher, J. 2011. Encapsulation of probiotic living cells: From laboratory scale to industrial applications. Journal of food Engineering, 104(4): 467-483.

Chávarri, M., Marañón, I., Ares, R., Ibáñez, F.C., Marzo, F. and Villarán, M.D.C. 2010. Microencapsulation of a probiotic and prebiotic in alginate-chitosan capsules improves survival in simulated gastro-intestinal conditions. International Journal of Food Microbiology, 142(1-2): 185-189.

Chen, M.J. and Chen, K.N. 2007. Applications of probiotic encapsulation in dairy products. In: Encapsulation and Controlled Release Technologies in Food Systems, 1st edition edited by Jamileh ML Wiley-Blackwell, USA 83-107.

Corona-Hernandez, R.I., Álvarez-Parrilla, E., LizardiMendoza, J., Islas-Rubio, A.R., de la Rosa, L.A. and Wall-Medrano, A. 2013. Structural stability and viability of microencapsulated probiotic bacteria: a review. Comprehensive Reviews in Food Science and Food Safety, 12(6): 614-628.

de Araújo Etchepare, M., Raddatz, G.C., de Moraes Flores, É.M., Zepka, L.Q., Jacob Lopes, E., Barin, J.S. and de Menezes, C.R. 2016. Effect of resistant starch and chitosan on survival of Lactobacillus acidophilus microencapsulated with sodium alginate. LWT-Food Science and Technology, 65: 511-517.

Desmond, C., Ross, R.P., O'callaghan, E., Fitzgerald, G. and Stanton, C. 2002. Improved survival of Lactobacillus paracasei NFBC 338 in spray-dried powders containing gum acacia. Journal of Applied Microbiology, 93(6): 1003-1011.

FAO/WHO. 2002. Food and Agriculture Organization of the United Nations/World Health Organization. Guidelines for the evaluation of probiotics in food. London, Ontario, Canada. April 30 and May 1, 2002.

Haralampu, S.G. 2000. Resistant starch-a review of the physical properties and biological impact of RS3. Carbohydrate Polymers, 41(3): 285-292.

Heidebach, T., Först, P. and Kulozik, U. 2009. Microencapsulation of probiotic cells by means of rennetgelation of milk proteins. Food Hydrocolloids, 23(7): 16701677.

Heidebach, T.Först, P. and Kulozik,U.2012. Microencapsulation of probiotic cells for food applications. Critical Reviews in Food Science and Nutrition, 52(4): 291-311. 
Iyer, C. and Kailaspathy, K. 2005. Effect of co-encapsulation of probiotics with prebiotics on increasing the viability of encapsulated bacteria under in vitro acidic and bile salt conditions and in yogurt. Food Microbiology and Safety, 70: 1.

Jyothi Sri, S., Seethadevi, A., Suria Prabha, K., Muthuprasanna, P. and Pavitra, P. 2012. Microencapsulation: a review. International Journal of Pharma and Bio Sciences, 3(1): 509-531.

Karthikeyan, N., Elango, A., Kumaresan, G., Gopalakrishnamurty, T.R. and Raghunath, B.V. 2014. Enhancement of probiotic viability in ice cream by microencapsulation. International Journal of Science and Environmental Technology, 3(1): 339-47.

Kavitake, D., Kandasamy, S., Devi, P.B. and Shetty, P.H. 2018. Recent developments on encapsulation of lactic acid bacteria as potential starter culture in fermented foods-A review. Food Bioscience, 21: 34-44.

Keshari, R., Rathore, K.S. and Bharkatiya, M. 2016. Microencapsulation drug delivery system-an overview. Pharma Tutor, 4(12): 20-28.

Krasaekoopt, W., Bhandari, B. and Deeth, H. 2003. Evaluation of encapsulation techniques of probiotics for yoghurt. International Dairy Journal, 13(1): 3-13.

Lee, J.S., Cha, D.S. and Park, H.J. 2004. Survival of freezedried Lactobacillus bulgaricus KFRI 673 in chitosan-coated calcium alginate microparticles. Journal of Agriculture and Food Chemistry, 52: 7300-7305.

Lian, W.C., Hsiao, H.C. and Chou, C.C. 2003. Viability of microencapsulated bifidobacteria in simulated gastric juice and bile solution. International Journal of Food Microbiology, 86(3): 293-301.

Livney, Y.D. 2010. Milk proteins as vehicles for bioactives. Current Opinion in Colloid and Interface Science, 15(1-2): 7383.

Mortazavian, A., Razavi, S.H., Ehsani, M.R. and Sohrabvandi, S. 2007. Principles and methods of microencapsulation of probiotic microorganisms. Iranian Journal of Biotechnology 5(1): 1-18.

Nawong, S., Oonsivilai, R., Boonkerd, N. and Hansen, L.T. 2016. Entrapment in foodgrade transglutaminase crosslinked gelatin- Bifidobacterium adolescentis maltodextrin microspheres protects Lactobacillus spp. during exposure to simulated gastro-intestinal juices. Food Research International, 85: 191-199.

Nazzaro, F., Orlando, P., Fratianni, F. and Coppola, R. 2012. Microencapsulation in food science and biotechnology. Current Opinion in Biotechnology, 23(2): 182186

O'riordan, K., Andrews, D., Buckle, K. and Conway, P. 2001. Evaluation of microencapsulation of a Bifidobacterium strain with starch as an approach to prolonging viability during storage. Journal of Applied Microbiology, 91(6): 1059-1066.
Ortakci, F., Broadbent, J.R., McManus, W.R. and McMahon, D.J. 2012. Survival of microencapsulated probiotic Lactobacillus paracasei LBC-1e during manufacture of Mozzarella cheese and simulated gastric digestion. Journal of Dairy Science, 95(11): 6274-6281.

Özer, B., Kirmaci, H.A., Senel, E., Atamer, M. and Hayaloglu, A. 2009. Improving the viability of Bifidobacterium bifidum BB-12 and Lactobacillus acidophilus LA-5 in white brined cheese by microencapsulation. International Dairy Journal, 19: 22-29.

Paim, D.R., Costa, S.D., Walter, E.H. and Tonon, R.V. 2016. Microencapsulation of probiotic jussara (Euterpe edulis M.) juice by spray drying. $L W T, 74:$ 21-25.

Patel, A. and Prajapati, J.B. 2013. Food and health applications of exopolysaccharides produced by lactic acid bacteria. Advances in Dairy Research, pp. 1-8.

Phoem, A.N., Chanthachum, S. and Voravuthikunchai, S.P. 2015. Applications of microencapsulated Bifidobacterium longum with Eleutherine americana in fresh milk tofu and pineapple juice. Nutrients, 7(4): 2469-2484.

Picot, A. and Lacroix, C. 2004. Encapsulation of bifidobacteria in whey protein-based microcapsules and survival in simulated gastrointestinal conditions and in yoghurt. International Dairy Journal, 14(6): 505-515.

Ranadheera, C.S., Evans, C.A., Adams, M.C. and Baines, S.K. 2015. Microencapsulation of Lactobacillus acidophilus LA-5, Bifidobacterium animalis subsp. lactis BB-12 and Propionibacterium jensenii 702 by spray drying in goat's milk. Small Ruminant Research, 123: 155-159.

Shah, A., Gani, A., Ahmad, M., Ashwar, B.A. and Masoodi, F.A. 2016. $\beta$-Glucan as an encapsulating agent: Effect on probiotic survival in simulated gastrointestinal tract. International Journal of Biological Macromolecules, 82: 217-222.

Silva, K.C.G., Cezarino, E.C., Michelon, M. and Sato, A.C.K. 2018. Symbiotic microencapsulation to enhance Lactobacillus acidophilus survival. LWT, 89: 503-509.

Song, C.E., Shim, H.H., Kuppusamy, P., Jeong, Y.I. and Lee, K.D. 2018. Potential sustainable properties of microencapsulated endophytic lactic acid bacteria (KCC42) in in-vitro simulated gastrointestinal juices and their fermentation quality of radish kimchi. BioMed Research International, Article ID 6015243, 1-10.

Su, L.C., Lin, C.W. and Chen, M.J. 2007. Development of an Oriental-style dairy product coagulated by microcapsules containing probiotics and filtrates from fermented rice. International Journal of Dairy Technology, 60(1): 49-54.

Sun, W. and Griffiths, M.W. 2000. Survival of bifidobacteria in yogurt and simulated gastric juice following immobilization in gellan-xanthan beads. International Journal of Food Microbiology, 61(1): 17-25. 
Tuomola, E.M., Ouwehand, A.C. and Salminen, S.J. 1999. The effect of probiotic bacteria on the adhesion of pathogens to human intestinal mucus. FEMS Immunology and Medical Microbiology, 26(2): 137-142.

Vidhyalakshmi, R., Bhakyaraj, R. and Subhasree, R.S. 2009. Encapsulation the future of probiotics-a review. Advances in Biological Research, 3(3-4): 96-103.

Vitaglione, P., Troise, A.D., De Prisco, A.C., Mauriello, G.L., Gokmen, V. and Fogliano, V. 2015. Use of microencapsulated ingredients in bakery products: technological and nutritional aspects. In Microencapsulation and Microspheres for Food Applications (pp. 301-311). Academic Press.

Ying, D., Schwander, S., Weerakkody, R., Sanguansri, L., Gantenbein-Demarchi, C. and Augustin, M.A. 2013. Microencapsulated Lactobacillus rhamnosus GG in whey protein and resistant starch matrices: Probiotic survival in fruit juice. Journal of Functional Foods, 5: 98-105
Yonekura, L., Sun, H., Soukoulis, C. and Fisk, I. 2014 Microencapsulation of Lactobacillus acidophilus NCIMB 701748 in matrices containing soluble fibre by spray drying: Technological characterization, storage stability and survival after in vitro digestion. Journal of Functional Foods, 6: 205-214.

Zhao, R., Sun, J., Torley, P., Wang, D. and Niu, S. 2008. Measurement of particle diameter of Lactobacillus acidophilus microcapsule by spray drying and analysis on its microstructure. World Journal of Microbiology and Biotechnology, 24(8): 1349-1354. 